\title{
Selective Internal Radiation Therapy_-Tackling the Tumor, Sparing the Organ
}

\author{
Janet C Miller, DPhil, ${ }^{1}$ Lawrence S Blaszkowsky, MD ${ }^{2}$ and Sanjeeva P Kalva, MD ${ }^{3}$
}

1. Instructor in Radiology; 2. Instructor in Medicine; 3. Assistant Professor of Radiology, Harvard Medical School

DOI: $10.17925 / O H R .2008 .04 .1 .68$

Primary liver cancer is the fifth most common cause of cancer in the world, with hepatocellular cancer (HCC) accounting for a large majority of cases. HCC has the highest incidence in East Asia and sub-Saharan Africa and is the fastest-growing cause of cancer-related death in the US. ${ }^{1}$ The liver is also a common site for metastases from other primary cancers, especially colorectal cancer because of portal venous drainage of the bowel. Approximately $20 \%$ of colon cancer patients are found to have stage IV disease at the time of initial diagnosis. ${ }^{2}$ In $40 \%$ of these cases metastases are confined to the liver, and most of these patients have no extra-hepatic metastases, even at the time of death. ${ }^{3}$

The only curative therapy for liver cancer is surgical removal of the tumor. ${ }^{4,5}$ Surgery may prolong survival in well-selected patients with liver metastases from colon cancer, ${ }^{3}$ although only $10-20 \%$ of patients with liver metastases are reasonable surgical candidates. ${ }^{4}$ If surgery is not

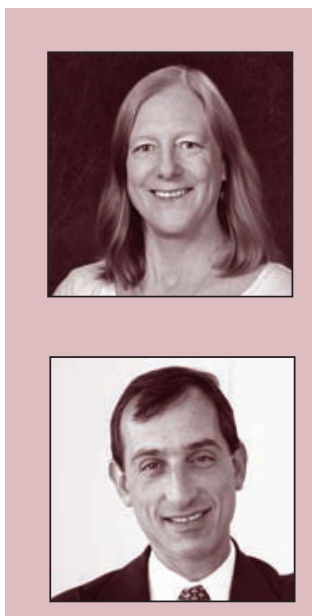

Janet C Miller, DPhil, is an Instructor in Radiology at Harvard Medical School and a Research Communication Specialist in the Department of Radiology at Massachusetts General Hospital, Boston. She is the author of a series of articles for physicians who refer patients to radiology, as well as several reviews on topics in radiology. She received her doctorate in biochemistry from the University of Oxford, England.

E: jcmiller@oartners.org

Lawrence S Blaszkowsky, MD, is an Instructor in Medicine at Harvard Medical School and an Assistant Physician and Medical Director of the Infusion Center at Massachusetts General Hospital in Boston. Previously, he was an Assistant Professor of Medicine at Tufts University School of Medicine, where his achievements include the establishment of a Multidisciplinary Hepatobiliary Tumor Center. Dr Blaszkowsky has authored several articles and has been an ad hoc reviewer for the American Journal of Clinical Oncology, Cancer, and Clinical Cancer Research. Dr Blaszkowsky received his medical degree from the State University of New York Health Science Center at Syracuse and completed his training in internal medicine at Mount Sinai Hospital in New York.

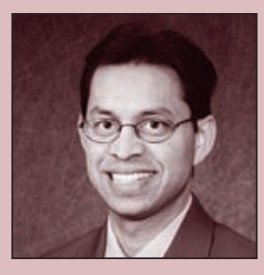

Sanjeeva P Kalva, MD, is an Assistant Professor of Radiology at Harvard Medical School and an Assistant Radiologist in the Department of Radiology, Division of Cardiovascular Imaging and Intervention at Massachusetts General Hospital in Boston. He is actively involved in transarterial therapy of liver tumors. His clinical and research interests are chemoembolization, selective internal radiotherapy (SIRT) and inferior vena cava filters. Dr Kalva received his medical degree from Kurnool Medical College in India and completed his radiology training at Nizam's Institute of Medical Sciences in Hyderabad, India, and at Massachusetts General Hospital in Boston. possible, local ablative therapies such as radiofrequency ablation are possible for some patients with a limited number of small tumors. ${ }^{6}$ For those with liver tumors who cannot be treated surgically or with ablative therapy, the prognosis is generally poor. Systemic chemotherapy can downsize some metastases to the point of resectability, ${ }^{3}$ but primary liver tumors do not generally respond to this treatment. ${ }^{1}$ External-beam radiation is limited by the relatively poor tolerance of the normal liver to standard radiation techniques.?

The vascular supply of liver tumors offers a unique opportunity to selectively deliver therapeutic agents to liver tumors while sparing the rest of the organ. Liver tumors receive $>80 \%$ of their blood supply via the hepatic artery, whereas the portal vein provides about $75 \%$ of the blood supply to the normal liver parenchyma. ${ }^{8}$ In addition, the microvascular density of liver tumors is three to 200 times greater than the surrounding liver parenchyma. ${ }^{9}$ These differences have been exploited in the development of treatments that are delivered via the hepatic artery, including transarterial chemotherapy, embolization to induce tumor ischemia, and embolization using drug-eluting microspheres or radiation-emitting microspheres. ${ }^{8}$

Two types of selective internal radiation therapy (SIRT) radiolabeled microspheres are available, one of which is made of glass (TheraSphere ${ }^{\circledR}$, MDS Norton Inc., Canada) and the second of which is made of resin (SIRSpheres ${ }^{\circledR}$, Sirtex Medical Inc., Australia). Both carry ${ }^{90}$ yttrium (Y), a beta emitter with a half-life of 64.1 hours and an average energy of 0.94 megaelectron volts (MeV), which corresponds to a maximum range of $1.1 \mathrm{~cm}$ within tissue with a mean path of $2.5 \mathrm{~mm}$. The two formulations differ considerably in terms of particle size and average dose of radioactivity delivered. ${ }^{10}$ In 2002, the US Food and Drug Administration (FDA) gave pre-market approval of SIR-Spheres as a brachytherapy device for the treatment of metastases from colorectal cancer. TheraSphere is approved as a humanitarian device for use in patients with unresectable HCC. ${ }^{8}$ Treatment with Sir-Spheres is considered to be the third-line option for patients with colorectal metastatic disease that is confined to the liver or with minimal extra-hepatic involvement. A few reports have suggested better long-term survival in patients with colorectal cancer when SIRT was used in conjunction with other chemotherapy. ${ }^{11}$ In most cases, patients have exhausted other treatment options and no longer respond to chemotherapy, cannot tolerate or refuse chemotherapy, or choose to receive both SIRT and chemotherapy. ${ }^{12}$

\section{Patient Selection and Preparation}

The first step in evaluating a patient for SIRT is proper staging to confirm that metastatic disease is largely confined to the liver and ensure that the 
1. Geller AC, Miller DR, Annas GD, et al., Melanoma incidence and mortality among US whites, 1969-1999, Jama, 2002;288:1719-20.

2. Jemal A, Siegel R, Ward E, et al., Cancer statistics, 2008, CA Cancer J Clin, 2008;58:71-96

3. Tarhini AA, Agarwala SS, Cutaneous melanoma: available therapy for metastatic disease, Dermatol Ther, 2006;19:19-25.

4. Weeraratna AT, Nagel JE, de Mello-Coelho V, Taub DD, Gene expression profiling: from microarrays to medicine, J Clin Immunol, 2004;24:213-24.

5. Vilain C, Vassart G, Small amplified RNA-SAGE, Methods Mol Biol, 2004;258:135-52.

6. Neilson L, Andalibi A, Kang D, et al., Molecular phenotype of the human oocyte by PCR-SAGE, Genomics, 2000;63:13-24.

7. Peters DG, Kassam AB, Yonas $H$, et al., Comprehensive transcript analysis in small quantities of mRNA by SAGE-lite, Nucleic Acids Res, 1999;27:e39.

8. Saha $S$, Sparks AB, Rago $C$, et al., Using the transcriptome to annotate the genome, Nat Biotechnol, 2002;20:508-12.

9. Heidenblut AM, Luttges J, Buchholz M, et al., aRNA-longSAGE: a new approach to generate SAGE libraries from microdissected cells, Nucleic Acids Res, 2004;32:e131.

10. Gowda M, Jantasuriyarat C, Dean RA, Wang GL, Robust-LongSAGE (RL-SAGE): a substantially improved LongSAGE method for gene discovery and transcriptome analysis, Plant Physiol, 2004:134:890-97.

11. Davies $H$, Bignell GR, Cox C, et al., Mutations of the BRAF gene in human cancer, Nature, 2002;417:949-54.

12. Monzon J, Liu L, Brill $H$, et al., CDKN2A mutations in multiple primary melanomas, N Engl J Med, 1998;338:879-87.

13. Papp T, Pemsel H, Zimmermann R, et al., Mutational analysis of the $\mathrm{N}$-ras, p53, p16INK4a, CDK4, and MC1R genes in human congenital melanocytic naevi, J Med Genet, 1999;36:610-14.

14. Fernandez L, Milne R, Bravo J, et al., MC1R: Three novel variants identified in a malignant melanoma association study in the Spanish population, Carcinogenesis, 2007;28(8):1659-64.

15. Bittner M, Meltzer $P$, Chen $Y$, et al., Molecular classification of cutaneous malignant melanoma by gene expression profiling, Nature, 2000;406:536-40.

16. Clark EA, Golub TR, Lander E, et al., Genomic analysis of metastasis reveals an essential role for RhoC, Nature, 2000:406:532-5.

17. Hoek KS, Schlegel NC, Brafford $P$, et al., Metastatic potential of melanomas defined by specific gene expression profiles with no BRAF signature, Pigment Cell Res, 2006; 19:290-302.

18. Hwang CS, Prieto VG, Diwan AH, et al., Changes in PERK1/2 and pAKT expression in melanoma lesions after imatinib treatment, Melanoma Res, 2008;18:241-5.

19. McLeod HL, Yu J, Cancer pharmacogenomics: SNPs, chips, and the individual patient, Cancer Invest, 2003;21:630-40.

20. Kallioniemi OP, Kallioniemi A, Sudar S, et al., Comparative genomic hybridization: a rapid new method for detecting and mapping DNA amplification in tumors, Semin Cancer Biol, 1993;4:41-6.

21. Komura D, Shen F, Ishikawa KR, et al., Genome-wide detection of human copy number variations using high-density DNA oligonucleotide arrays, Genome Res, 2006;16:1575-84.

22. Benbow $\mathrm{U}$, Tower $\mathrm{GB}$, Wyatt $\mathrm{CA}$, et al., High levels of MMP-1 expression in the absence of the $2 \mathrm{G}$ single nucleotide polymorphism is mediated by $\mathrm{p} 38$ and ERK1/2 mitogen-activated protein kinases in VMM5 melanoma cells, J Cell Biochem, 2002;86:307-19.

23. Howell WM, Turner SJ, Theaker JM, Cytokine gene single nucleotide polymorphisms and susceptibility to and prognosis in cutaneous malignant melanoma, Eur J Immunogenet, 2003;30:409-14.

24. James MR, Roth RB, Shi MM, et al., BRAF polymorphisms and risk of melanocytic neoplasia, I Invest Dermatol, 2005;125:1252-8.

25. James MR, Hayward NK, Dumenil T, et al., Epidermal growth factor gene (EGF) polymorphism and risk of melanocytic neoplasia, J Invest Dermatol, 2004;123:760-62.

26. Garraway LA, Widlund HR, Rubin MA, Integrative genomic analyses identify MITF as a lineage survival oncogene amplified in malignant melanoma, Nature, 2005;436:117-22.

27. Worley LA, Long MD, Onken MD, Harbour JW, Micro-RNAs associated with metastasis in uveal melanoma identified by multiplexed microarray profiling, Melanoma Res, 2008;18:184-90.

28. Weeraratna AT, Jiang Y, Hostetter $G$, et al., Wnt5a signaling directly affects cell motility and invasion of metastatic melanoma, Cancer
Cell, 2002;1:279-88.

29. Miyazono K, Ten Dijke P, Ichijo H, Heldin CH, Receptors for transforming growth factor-beta, Adv Immunol, 1994;55:181-20.

30. Blobe GC, Schiemann WP, Lodish HF, Role of transforming growth factor beta in human disease, N Engl J Med, 2000;342:1350-58.

31. Dhillon AS, Hagan S, Rath 0 , Kolch W, MAP kinase signalling pathways in cancer, Oncogene, 2007;26:3279-90.

32. Marquette A, Bagot M, Bensussan A, Dumaz N, Recent discoveries in the genetics of melanoma and their therapeutic implications, Arch Immunol Ther Exp, 2007;55:363-72.

33. Weeraratna AT, A Wnt-er wonderland - the complexity of Wnt signaling in melanoma, Cancer Metastasis Rev, 2005;24237-50

34. O' Satyamoorthy K, Li G, Vaidya B, et al., Insulin-like growth factor-1 induces survival and growth of biologically early melanoma cells through both the mitogen-activated protein kinase and beta-catenin pathways, Cancer Res, 2001;61:7318-24.

35. Slusarski DC, Corces VG, Moon RT, Interaction of Wnt and a Frizzled homologue triggers G-protein-linked phosphatidylinositol signalling Nature, 1997;390:410-13.

36. Kuhl M, The WNT/calcium pathway: biochemical mediators, tools and future requirements, Front Biosci, 2004;9:967-74.

37. Kohn AD, Moon RT, Wnt and calcium signaling: beta-cateninindependent pathways, Cell Calcium, 2005;38:439-46.

38. Dissanayake SK, Wade M, Johnson CE, et al., The Wnt5A/protein kinase C pathway mediates motility in melanoma cells via the inhibition of metastasis suppressors and initiation of an epithelial to mesenchymal transition, J Biol Chem, 2007;282:17259-71.

39. Foser S, Redwanz I, Ebeling M, et al., Interferon-alpha and transforming growth factor-beta co-induce growth inhibition of human tumor cells, Cell Mol Life Sci, 2006;63:2387-96.

40. Massague J, Blain SW, Lo RS, TGFbeta signaling in growth control, cancer, and heritable disorders, Cell, 2000;103:295-309.

41. Berk M, Desai SY, Heyman HC, Colmenares C, Mice lacking the ski proto-oncogene have defects in neurulation, craniofacial, patterning, and skeletal muscle development, Genes Dev, 1997;11:2029-39.

42. Luo K, Stroschein SL, Wang W, et al., The Ski oncoprotein interacts with the Smad proteins to repress TGFbeta signaling, Genes Dev, 1999;13:2196-2206

43. Wang W, Mariani FV, Harland RM, Luo K, Ski represses bone morphogenic protein signaling in Xenopus and mammalian cells, Proc Natl Acad Sci U S A, 2000;97:14394-9.

44. Heider TR, Lyman S, Schoonhoven R, Behrns KE, Ski promotes tumo growth through abrogation of transforming growth factor-beta signaling in pancreatic cancer, Ann Surg, 2007;246:61-8.

45. McKay MM, Morrison DK, Integrating signals from RTKs to ERK/MAPK, Oncogene, 2007;26:3113-21.

46. Thompson N, Lyons J, Recent progress in targeting the Raf/MEK/ERK pathway with inhibitors in cancer drug discovery, Curr Opin Pharmacol, 2005;5:350-56.

47. Fresno Vara JA, Casado E, de Castro J, et al., PI3K/Akt signalling pathway and cancer, Cancer Treat Rev, 2004;30:193-204.

48. Manning BD, Cantley LC, AKT/PKB signaling: navigating downstream, Cell, 2007;129:1261-74.

49. Kielhorn E, Provost E, Olsen D, et al., Tissue microarray-based analysis shows phospho-beta-catenin expression in malignant melanoma is associated with poor outcome, Int I Cancer, 2003;103:652-6.

50. Demunter A, Libbrecht L, Degreef $H$, et al., Loss of membranous expression of beta-catenin is associated with tumor progression in cutaneous melanoma and rarely caused by exon 3 mutations, Mod Pathol, 2002;15:454-61.

51. Kim SE, Lee WJ, Choi KY, The PI3 kinase-Akt pathway mediates Wnt3a-induced proliferation, Cell Signal, 2007;19:511-18.

52. Levy C, Khaled M, Fisher DE, MITF: master regulator of melanocyte development and melanoma oncogene, Trends Mol Med, 2006:12:406-14.

53. Fishman P, Madi L, Bar-Yehuda S, et al., Evidence for involvement of Wnt signaling pathway in IB-MECA mediated suppression of melanoma cells, Oncogene, 2002;21:4060-64.

54. Koyanagi M, Haendeler J, Badorff C, et al., Non-canonical Wnt signaling enhances differentiation of human circulating progenitor cells to cardiomyogenic cells, J Biol Chem, 2005;280:16838-42.

55. Dai Y, Khanna P, Chen S, et al., Statins synergistically potentiate 7-hydroxystaurosporine (UCN-01) lethality in human leukemia and myeloma cells by disrupting Ras farnesylation and activation, Blood, 2007; 109:4415-23

56. Pei XY, Li W, Dai Y, et al., Dissecting the roles of checkpoint kinase $1 / C D C 2$ and mitogen-activated protein kinase kinase $1 / 2$ /extracellular signal-regulated kinase $1 / 2$ in relation to 7-hydroxystaurosporine-induced apoptosis in human multiple myeloma cells, Mol Pharmacol, 2006;70:1965-73.

57. Tsubaki M, Matsuoka $H$, Yamamoto $C$, et al., The protein kinase $C$ inhibitor, $\mathrm{H} 7$, inhibits tumor cell invasion and metastasis in mouse melanoma via suppression of ERK1/2, Clin Exp Metastasis, 2007; $24: 431-8$

58. Nishida S, Yoshioka S, Kinoshita-Kimoto S, et al.,Pre-treatment with PKC inhibitor triggers TNF-alpha induced apoptosis in TNF-alpharesistant B16 melanoma BL6 cells, Life Sci, 2003;74:781-92.

59. Kusaba $H$, Ghosh $P$, Derin $R$, et al., Interleukin-12-induced interferon-gamma production by human peripheral blood $\mathrm{T}$ cells is regulated by mammalian target of rapamycin (mTOR), J Biol Chem, 2005;280:1037-43

60. Hudes $G$, Carducci M, Tomczak $P$, et al., Temsirolimus, interferon alfa, or both for advanced renal-cell carcinoma, N Engl J Med, 2007;356:2271-81.

61. Margolin K, Longmate J, Baratta T, et al., CCl-779 in metastatic melanoma: a phase II trial of the California Cancer Consortium, Cancer, 2005; 104:1045-8.

62. Garnett MJ, Marais R, Guilty as charged: B-RAF is a human oncogene, Cancer Cell, 2004;6:313-19.

63. Pollock PM, Meltzer PS, A genome-based strategy uncovers frequent BRAF mutations in melanoma, Cancer Cell, 2002;2:5-7.

64. Eisen T, Ahmad T, Flaherty KT, et al., Sorafenib in advanced melanoma: a Phase II randomised discontinuation trial analysis, Br J Cancer, 2006;95:581-6.

65. Amaravadi RSL, McDermott DF, Kramer A, et al., Updated results of a randomized phase II study comparing two schedules of temozolomide in combination with sorafenib in patients with advanced melanoma, ASCO Meeting Abstracts, 2007; abstract 8527.

66. Atkins MB, Lotze MT, Dutcher JP, Fisher RI, Weiss G, et al., Highdose recombinant interleukin 2 therapy for patients with metastatic melanoma: analysis of 270 patients treated between 1985 and 1993, J Clin Oncol, 1999:17:2105-16.

67. Kirkwood JM, Strawderman MH, Ernstoff MS, et al., Interferon alfa$2 \mathrm{~b}$ adjuvant therapy of high-risk resected cutaneous melanoma: the Eastern Co-operative Oncology Group Trial EST 1684, J Clin Oncol, 1996;14:7-17.

68. Ribas A, Camacho LH, Lopez-Berestein G, et al., Antitumor activity in melanoma and anti-self responses in a phase I trial with the anticytotoxic T lymphocyte-associated antigen 4 monoclonal antibody CP675,206, J Clin Oncol, 2005;23:8968-77.

69. Phan GQ, Yang JC, Sherry RM, et al., Cancer regression and autoimmunity induced by cytotoxic T lymphocyte-associated antigen 4 blockade in patients with metastatic melanoma, Proc Natl Acad Sci U S A, 2003;100:8372-7.

70. Katipamula R, Markovic SN, Emerging therapies for melanoma, Expert Rev Anticancer Ther, 2008:8:553-60.

71. Rosenberg SA, Yang JC, Schwartzentruber DJ, et al., Immunologic and therapeutic evaluation of a synthetic peptide vaccine for the treatment of patients with metastatic melanoma, Nat Med, 1998:4:321-7.

72. Kirkwood JM, Land LS, et al., E1696: Final analysis of the clinical and immunological results of a multicenter ECOG phase II trial of multi-epitope peptide vaccination for stage IV melanoma with MART-1 (27-35), gp100 (209-217, 210M and tyrosinase (368-376, 370D) +/- IFN-a2b and GM-CSF, Am Soc Clin Oncol J, 2004

73. Zhao Y, Zheng Z, Cohen CJ, et al., High-efficiency transfection of primary human and mouse T lymphocytes using RNA electroporation, Mol Ther, 2006;13:151-9.

74. Morgan RA, Dudley ME, Wunderlich JR, et al., Cancer Regression in Patients After Transfer of Genetically Engineered Lymphocytes, Science, 2006;314126-9.

75. Sosman JA, Weeraratna AT, Sondak VK, When will melanoma vaccines be proven effective?, I Clin Oncol, 2004;22:387-9

76. Lorigan $P$, Eisen $T$, Hauschild A, Systemic therapy for metastatic malignant melanoma - from deeply disappointing to bright future? Exp Dermatol, 2008:17:383-94. 
patient meets the selection criteria in order to minimize the likelihood of life-threatening complications (see Table 1). A computed tomography (CT) (see Figure $1 A$ ) or magnetic resonance (MR) examination will establish tumor burden in the liver. A positron emission tomography (PET) (see Figure $1 B$ ) or PET/CT examination is helpful to evaluate the extent of metastasis as well as to provide a baseline measure of the metabolic activity of the tumors, which can be used to assess the response to SIRT. Only patients with few or no extra-hepatic metastases will benefit from SIRT.

Laboratory evaluations are essential in order to determine whether patients have adequate liver function (bilirubin $<2 \mathrm{mg} / \mathrm{dl}$ ) and renal function (epidermal growth factor receptor [eGFR] $>30 \mathrm{ml} /$ minute $/ \mathrm{m}^{2}$ ). Patient performance status should be graded according to the Eastern Co-operative Oncology Group (ECOG) scheme. Patients with compromised performance (score of two to four) have an increased risk for treatment-related morbidity. ${ }^{8}$ The next step is an angiographic examination to assess the anatomy of the celiac, superior mesenteric, and hepatic arteries. A detailed, meticulous angiography (see Figure 2A) of the hepatic arteries is important. First, it is useful to determine whether a whole-liver or lobar approach is appropriate for infusion of ${ }^{90} \mathrm{Y}$ microspheres, second, to isolate the arterial supply to one or two arteries by embolizing the multiple feeders so as to simplify the treatment, and third, to occlude extra-hepatic arteries such as the gastroduodenal artery (GDA), right gastric artery (RGA) (see Figure 2B), and others to prevent non-target embolization because this would result in radiation-induced gastroduodenal ulcers. In addition, portal vein patency should be assessed because of the danger of acute liver failure if there is an occlusion. However, patients with a thrombosis in a first-order branch of the portal vein appear to tolerate SIRT. ${ }^{8}$

The fourth step in treatment planning is to determine the degree of hepatopulmonary shunting due to the tumor. This phenomenon is more common with HCC. The assessment is accomplished by infusing macro-aggregated albumin (MAA) particles labeled with 99mTc into the proper hepatic artery. MAA particles are similar in size to SIR-Spheres and provide information about blood flow from the hepatic artery, in particular that to the lungs and abdominal organs. Planar scintigraphy is used to assess the distribution of radioactivity: if $>20 \%$ of the radioactivity reaches the lungs (see Figure $3 A$ ), SIRT is contraindicated because of the risk of developing radiation pneumonitis: if $10-20 \%$ reaches the lungs, it is possible to perform SIRT with a reduced dose of $90 Y$; if $<10 \%$ reaches the lungs (see Figure $3 B$ ), the procedure can be conducted using the standard protocol. ${ }^{8}$

The dose is calculated on the assumptions that the deposition of SIR-Spheres is influenced by the extent of the tumor burden and that the resulting deposition will not be uniform. Two methods of dose calculation are used, one based on body surface area and the other on empirical data. The former uses the equation $\mathrm{A}=$ (body surface area [BSA] $-0.2)+$ tumor volume (TV)/(TV plus liver volume [LV]), where $A$ is the activity of the ${ }^{90} \mathrm{Y}$ content of the microspheres in gigabecquerel $(\mathrm{GBq})$. The latter method assumes that if the tumor involves $<25 \%$ of the total liver volume, the nominal dose is $2 \mathrm{GBq}{ }^{2}$ This rises to $5 \mathrm{GBq}$ if the tumor burden is $25-50 \%$, and $3 \mathrm{GBq}$ if the tumor involves $>50 \%$ of the total LV. These doses are reduced to $80 \%$ of the nominal dose if the hepatopulmonary shunt fraction is $10-15 \%$, and $60 \%$ of the nominal dose if the hepatopulmonary shunt fraction is $15-20 \% .^{8}$
Table 1: Patient Selection Criteria for Selective Internal Radiation Therapy

Non-resectable liver tumors and ineligible for other local/regional therapies Previously treated unsuccessfully with intravenous chemotherapy

No prior external-beam radiation

Little or no extra-hepatic malignancy

No significant hepatopulmonary shunting

No recent (within past 2 months) treatment with capecitabine

Serum bilirubin $\leq 2 \mathrm{mg} / \mathrm{dl}$

Creatinine $\leq 1.8 \mathrm{mg} / \mathrm{dl}$

Platelet count $\geq 50,000 / \mu l$

No portal vein occlusion with hepato-fugal flow

Low risk for microsphere implantation in non-occludable vessels to other organs

Life expectancy $>6$ weeks

Eastern Co-operative Oncology Group performance status $\leq 3$

Figure 1: Imaging of the Liver in a Patient with Colon Cancer

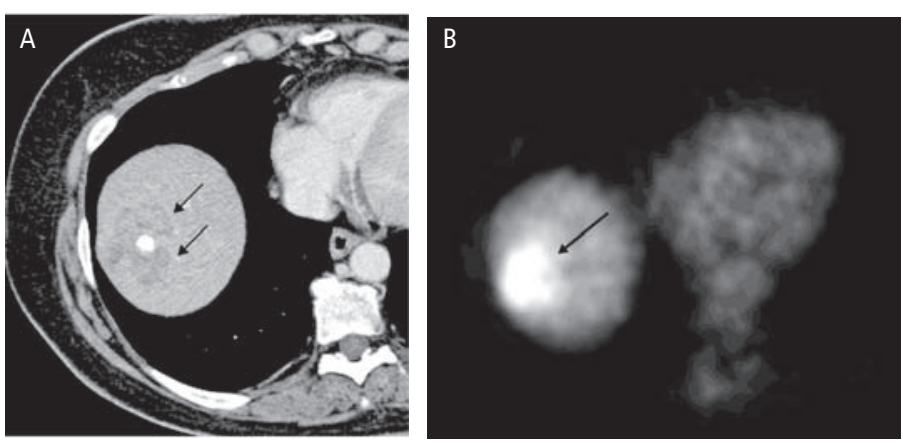

A: Axial computed tomography (CT) of the liver in a patient with colon cancer shows metastasis (arrows) in segment eight of the liver; B: Positron emission tomography (PET) image of same patient showing high focal uptake (arrow) of ${ }^{18}$ F-fluoro-deoxy-glucose in the tumor. With permission from Kalva et al. ${ }^{8}$

Figure 2: Detailed Angiography of the Hepatic Arteries
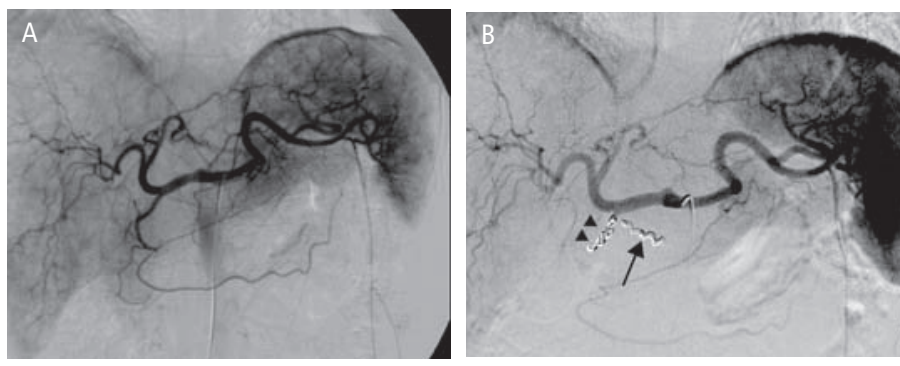

A: Pre-treatment angiogram shows normal celiac artery; B: Angiogram after coil embolization of the gastroduodenal artery (GDA) (single arrow) and right gastric artery (RGA) (two arrows) shows successful embolization with no flow in to these vessels. Coil embolization is performed to prevent accidental reflux of SIR-Spheres from the hepatic artery to the gut vessels.

\section{The Procedure}

For each procedure, the SIR-Spheres are delivered in a kit that includes apparatus that shields the radiation and provides a closed circuit to prevent spills (see Figure 3). Patients are not allowed to eat or drink anything for six hours prior to the procedure, which is performed under conscious sedation and local anesthesia at the catheter insertion site. An angiographic catheter is inserted into the femoral artery and guided into the arterial circulation of the liver. If the entire liver is to be treated, the microspheres are infused from a microcatheter into the proper hepatic 
Table 2: Response to Selective Internal Radiation Therapy

\begin{tabular}{|c|c|c|c|c|c|}
\hline $\begin{array}{l}\text { Patients } \\
\text { (Number) }\end{array}$ & $\begin{array}{l}\text { Primary Tumor } \\
\text { (Number) }\end{array}$ & Trial Design & Response to Treatment & $\begin{array}{l}\text { Major Complications of SIRT } \\
\text { (Number) }\end{array}$ & Reference \\
\hline 36 & CRC & $\begin{array}{l}\text { Prospective, randomized, } \\
\text { SIRT + HAC versus HAC }\end{array}$ & $\begin{array}{l}\text { Median time to progression: } \\
15.9 \text { versus } 9.7 \text { months }(p<0.001)^{a}\end{array}$ & None reported & Gray et al. ${ }^{11}$ \\
\hline 21 & CRC & $\begin{array}{l}\text { Prospective, randomized: } \\
\text { chemotherapy + SIRT versus chemotherapy }\end{array}$ & $\begin{array}{l}\text { Median survival: } 29.4 \text { versus } \\
12.8 \text { months }\end{array}$ & $\begin{array}{l}\text { Liver abscess (1) } \\
\text { Radiation-induced cirrhosis (1) }\end{array}$ & Van Hazel et al. ${ }^{22}$ \\
\hline 39 & $\begin{array}{l}\text { CRC (17) } \\
\text { BC (7) } \\
\text { HCC (4) } \\
\text { Other (6) }\end{array}$ & SIRT alone & $\begin{array}{l}\text { Median time to progression: } \\
6.5 \text { months } \\
8.5 \text { months } \\
>8^{\mathrm{b}} \text { months } \\
8^{\mathrm{c}} \text { months }\end{array}$ & $\begin{array}{l}\text { Gastric ulcer (2) } \\
\text { Pancreatitis (1) }\end{array}$ & Jacobs et al. ${ }^{15}$ \\
\hline 100 & CRC & SIRT alone & $\begin{array}{l}\text { Median survival: } \\
\text { Group 1:d } 8.7 \text { months } \\
\text { Group 2: } 18.5 \text { months }\end{array}$ & $\begin{array}{l}\text { Gastric ulcer (8) } \\
\text { Radiation hepatitis (1 fatal) } \\
\text { Pancreatitis ( } 1 \text { fatal) } \\
\text { Liver abscess (1) }\end{array}$ & Stubbs et al. ${ }^{14}$ \\
\hline 208 & CRC & Multicenter study, SIRT alone & $\begin{array}{l}\text { Median survival: } \\
\text { Responders ( } 90 \%): 10.5 \text { months } \\
\text { Non-responders (10\%): } 4.5 \text { months }\end{array}$ & $\begin{array}{l}\text { Gastric ulcer (12) } \\
\text { Pulmonary embolus (1) }\end{array}$ & Kennedy et al. ${ }^{13}$ \\
\hline 30 & CRC & $\begin{array}{l}\text { SIRT alone; previously treated } \\
\text { with fluorouracil }\end{array}$ & $\begin{array}{l}\text { Median time to progression: } \\
\text { All: } 5.3 \text { months } \\
\text { Partial responders: } 9.2 \text { months }\end{array}$ & Gastric ulcer (4) & Lim et al. ${ }^{16}$ \\
\hline 21 & $\begin{array}{l}\text { CRC (10) } \\
\text { Primary liver (3) } \\
\text { Other (8) }\end{array}$ & SIRT alone & $\begin{array}{l}\text { Median survival: } \\
\text { Group 1:d } 5 \text { months } \\
\text { Group 2: } 10 \text { months }\end{array}$ & $\begin{array}{l}\text { Cholecystitis, fibrosis, and } \\
\text { portal hypertension (1) } \\
\text { Gastric ulcer (1) } \\
\text { Radiation hepatitis (2) }\end{array}$ & Jiao et al. ${ }^{23}$ \\
\hline 12 & CRC & $\begin{array}{l}\text { SIRT alone (7) } \\
\text { SIRT and chemotherapy (6) } \\
\text { SIRT and radiofrequency ablation (1) }\end{array}$ & Median survival: 4.5 months & Gastric ulcer (1) & Murthy et al. ${ }^{17}$ \\
\hline 24 & $\mathrm{HCC}$ & SIRT alone & Median survival: 7 months & Jaundice (2) & Sangro et al. ${ }^{18}$ \\
\hline 20 & CRC & SIRT + FOLFOX & $\begin{array}{l}\text { Median time to progression: } \\
\text { Group 1:d } 12.3 \text { months }(13 / 20) \\
\text { Group 2: } 14.2 \text { months }(7 / 20)\end{array}$ & Gastric ulcer (2) & Sharma et al. ${ }^{24}$ \\
\hline 24 & $\begin{array}{l}\text { CRC (7) } \\
\text { HCC (7) } \\
\text { Other (10) }\end{array}$ & SIRT alone & $\begin{array}{l}\text { Median survival: } \\
9 \text { months } \\
3.5 \text { months } \\
5.8 \text { months }\end{array}$ & Gastric ulcer (1) & Rowe et al. ${ }^{25}$ \\
\hline
\end{tabular}

$B C=$ breast cancer; $C R C=$ colorectal cancer; HAC = hepatic artery chemotherapy; HCC = hepatocellular carcinoma; SIRT = selective internal radiation therapy. a. Treated with SIRT and intra-HAC.

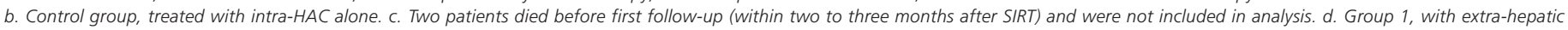
disease; Group 2, no extra-hepatic disease. e. No progressive disease in four patients at time of report; 15-18 months after SIRT, 53\% of patients with progressive disease developed lung metastases, two patients were downstaged, and liver tumors were surgically resected.

artery. In some cases, especially if there are many small tumors scattered throughout the liver, the microspheres are administered in two treatment sessions, with an infusion into the right hepatic artery in the first session and into the left hepatic artery in the second treatment session. Once the infusion is completed, the microcatheter is withdrawn into the angiographic catheter prior to its removal to prevent unwanted deposition of radioactivity.

Immediately after completion of the procedure, planar scintigraphy or single photon emission CT (SPECT) is used to assess the distribution of $90 Y$ in the liver and to detect misplacement of the microspheres in the gastrointestinal tract. Patients are required to lie flat for two to six hours after the procedure and generally stay in hospital overnight for observation. Precautions to prevent unnecessary exposure to radiation in people other than the patient include avoiding contact with pregnant women and not permitting children to sit on the patient's lap for a few days following the procedure.

\section{Follow-up}

Patients should be evaluated at approximately one and three months after the procedure, and at three-monthly intervals thereafter. Both laboratory tests for liver function and imaging tests for tumor burden are necessary to assess tumor response. Two weeks after SIRT, the level of carcinoembryonic antigen (CEA) is often higher than at the time of treatment, but it declines by six weeks after treatment. ${ }^{13}$ CEA reduction from the pre-treatment value within two months of SIRT confers significant survival benefit. ${ }^{14}$ Although the standard method for determining tumor response is measuring tumor size, size alone is not reliable because necrosis, hemorrhage, and edema can cause an initial increase in size in a tumor that is responding ${ }^{8}$ Despite this limitation, the majority of patients have a partial response or stable disease after SIRT by CT criteria (see Figure $4 A$ ), and most die as a result of extrahepatic disease. ${ }^{13-18}$ In some cases, new liver tumors develop. Provided that there are no significant metastases elsewhere, patients can be re-treated with SIRT. 
Figure 3: Scintigraphy Images of the Thorax and the Liver
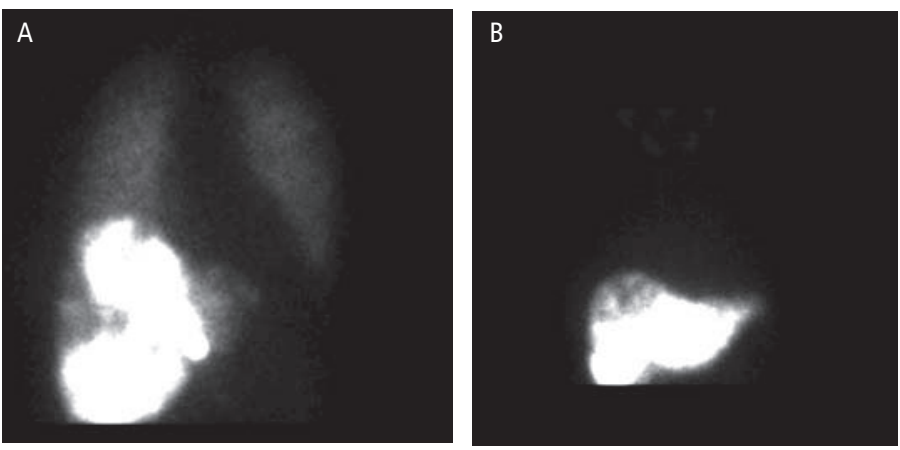

Scintigraphy images of the thorax and the liver following intra-arterial administration of

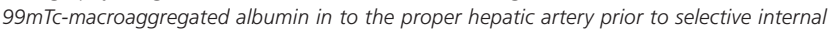
radiation therapy (SIRT) procedure. In patient $A$ the hepatopulmonary shunt (HS) is $>20 \%$, which makes the patient ineligible for SIRT. In patient B the HS is $<5 \%$.

PET is more sensitive than CT for the assessment of early response (see Figure 4B), and in one study 12 of 14 patients had a drop in standardized uptake value (SUV) on fluoro-deoxy-glucose (FDG)-PET imaging after six weeks, whereas only two of 15 patients had smaller lesions on $\mathrm{CT}$ at this time. ${ }^{19}$ In addition, there is some evidence that an increase in apparent diffusion constant, measured by diffusion-weighted MR imaging, may be a useful indicator of early response and the development of tumor necrosis..20,21 Early evidence of response may be useful in guiding further treatment.

\section{Patient Outcome}

There have been two prospective, randomized clinical trials of SIRT, one of which compared SIRT with hepatic artery chemotherapy (HAC), ${ }^{11}$ while the other compared SIRT alone with SIRT and systemic chemotherapy. ${ }^{22}$ Both showed that SIRT prolonged the lives of patients with liver
Figure 4: Follow-up Imaging of the Patient in Figure 1

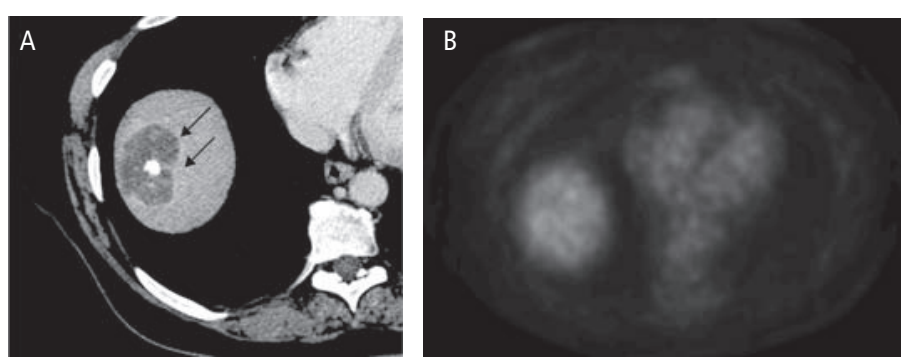

A: Computed tomography (CT) image of the same patient as in Figure 1 six weeks after treatment with selective internal radiation therapy (SIRT) showing complete necrosis of the tumor (arrows). B: Positron emission tomography image of the same patient six weeks after treatment shows diminished uptake of ${ }^{18}$ F-fluoro-deoxy-glucose (arrow). With permission from Kalva et al. ${ }^{6}$

metastases from colorectal cancer (see Table 2). Since then, there have been a number of reports on patient outcome following SIRT alone or combined with other treatments (see Table 2).

\section{Summary}

For the most part, complications are not serious. Low-grade fever, loss of appetite, lethargy, and fatigue are common for up to six weeks after the procedure. Acute abdominal/epigastric pain and/or nausea has been reported to occur in $30 \%$ of patients. ${ }^{13}$ The most common major complication is radiation-induced gastric ulcer (see Table 2), which can occur if any microspheres lodge in the blood vessels of the stomach. Unfortunately, radiation-induced ulcers do not heal well and can be distressing, and are best avoided by aggressive embolization of collateral vessels that supply the gut. Rare complications include radiation-induced pancreatitis and jaundice. The latter is more likely to occur in patients with HCC. These complications can be minimized by meticulous patient selection and preparation procedures.
1. El-Serag HB, Rudolph $\mathrm{KL}$, Hepatocellular carcinoma: epidemiology and molecular carcinogenesis, Gastroenterology, 2007;132(7): 2557-76.

2. Jemal A, Siegel $R$, Ward $E$, et al., Cancer statistics, 2007, CA Cancer I Clin, 2007;57(1):43-66.

3. Chong $G$, Cunningham $D$, Improving long-term outcomes for patients with liver metastases from colorectal cancer, J Clin Oncol, 2005;23(36):9063-6.

4. Sasson $A R$, Sigurdson ER, Surgical treatment of liver metastases, Semin Oncol, 2002;29(2):107-18.

5. Okuda K, Ohtsuki T, Obata H, et al., Natural history of hepatocellular carcinoma and prognosis in relation to treatment. Study of 850 patients, Cancer, 1985;56(4):918-28.

6. Tanabe KK, Curley SA, Dodd GD, et al., Radiofrequency ablation: the experts weigh in, Cancer, 2004;100(3):641-50.

7. Welsh JS, Kennedy AS, Thomadsen B, Selective Internal Radiation Therapy (SIRT) for liver metastases secondary to colorectal adenocarcinoma, Int J Radiat Oncol Biol Phys, 2006;66(Suppl. 2): S62-73.

8. Kalva SP, Thabet A, Wicky S, Recent advances in transarterial therapy of primary and secondary liver malignancies, Radiographics, 2008;28(1):101-17.

9. Lien WM, Ackerman NB, The blood supply of experimental liver metastases. II. A microcirculatory study of the normal and tumor vessels of the liver with the use of perfused silicone rubber, Surgery, 1970;68(2):334-40.

10. Sangro B, Radioembolization - A new treatment for primary and secondary liver tumors, European Oncological Disease, 2006:36-8.

11. Gray B, Van Hazel G, Hope M, et al., Randomised trial of
SIR-Spheres plus chemotherapy vs. chemotherapy alone for treating patients with liver metastases from primary large bowel cancer, Ann Oncol, 2001;12(12):1711-20.

12. Kennedy A, Nag S, Salem R, et al., Recommendations for radioembolization of hepatic malignancies using yttrium-90 microsphere brachytherapy: a consensus panel report from the radioembolization brachytherapy oncology consortium, Int J Radiat Oncol Biol Phys, 2007;68(1):13-23.

13. Kennedy AS, Coldwell D, Nutting C, et al., Resin ${ }^{90}$ Y-microsphere brachytherapy for unresectable colorectal liver metastases: modern USA experience, Int I Radiat Oncol Biol Phys, 2006:65(2):412-25

14. Stubbs RS, O'Brien I, Correia MM, Selective internal radiation therapy with ${ }^{90} \mathrm{Y}$ microspheres for colorectal liver metastases, ANZ I Surg, 2006;76(8):696-703.

15. Jakobs TF, Hoffmann RT, Poepperl G, et al., Mid-term results in otherwise treatment refractory primary or secondary liver confined tumours treated with selective internal radiation therapy (SIRT) using 90Yttrium resin-microspheres, Eur Radiol, 2007;17(5): 1320-30.

16. Lim L, Gibbs $P$, Yip $D$, et al., A prospective evaluation of treatment with Selective Internal Radiation Therapy (SIR-spheres) in patients with unresectable liver metastases from colorectal cancer previously treated with 5-FU based chemotherapy, BMC Cancer, 2005;5:132.

17. Murthy $R$, Xiong $H$, Nunez $R$, et al., Yttrium 90 resin microspheres for the treatment of unresectable colorectal hepatic metastases after failure of multiple chemotherapy regimens: preliminary results, J Vasc Interv Radiol, 2005;16(7):937-45.

18. Sangro B, Bilbao Jl, Boan J, et al., Radioembolization using
${ }^{90} \mathrm{Y}$-resin microspheres for patients with advanced hepatocellular carcinoma, Int J Radiat Oncol Biol Phys, 2006;66(3):792-800.

19. Szyszko T, Al-Nahhas A, Canelo R, et al., Assessment of response to treatment of unresectable liver tumours with $90 \mathrm{Y}$ microspheres: value of FDG PET versus computed tomography, Nucl Med Commun, 2007;28(1):15-20.

20. Deng J, Miller FH, Rhee TK, et al., Diffusion-weighted MR imaging for determination of hepatocellular carcinoma response to $90 \mathrm{Y}$ radioembolization, J Vasc Interv Radiol, 2006;17(7):1195-1200.

21. Kamel IR, Reyes DK, Liapi E, et al., Functional MR imaging assessment of tumor response after ${ }^{90} \mathrm{Y}$ microsphere treatment in patients with unresectable hepatocellular carcinoma, J Vasc Interv Radiol, 2007;18(1 Pt 1):49-56.

22. Van Hazel G, Blackwell A, Anderson J, et al., Randomised phase 2 trial of SIR-Spheres plus fluorouracil/leucovorin chemotherapy versus fluorouracil/leucovorin chemotherapy alone in advanced colorectal cancer, J Surg Oncol, 2004;88(2):78-85.

23. Jiao LR, Szyszko T, Al-Nahhas A, et al., Clinical and imaging experience with yttrium-90 microspheres in the management of unresectable liver tumours, Eur I Surg Oncol, 2007;33(5):597-602.

24. Sharma RA, Van Hazel GA, Morgan B, et al., Radioembolization of liver metastases from colorectal cancer using yttrium-90 microspheres with concomitant systemic oxaliplatin, fluorouracil, and leucovorin chemotherapy, J Clin Oncol, 2007;25(9):1099-1106.

25. Rowe BP, Weiner R, Foster J, Dowsett $R$, ${ }^{90}$ Yttrium microspheres for nonresectable liver cancer: the University of Connecticut Health Center experience, Conn Med, 2007;71(9):523-8. 